\title{
Innovations in Market-Led Extension
}

\author{
D.K. Krishna ${ }^{1}$, N.V. Kumbhare ${ }^{2}$, Itigi Prabhakar ${ }^{3}$, B.S. Swetha ${ }^{3}$ and N. Ashoka ${ }^{3 *}$ \\ ${ }^{1}$ ICAR-IARI, New Delhi, India \\ ${ }^{2} A T I C$, ICAR-IARI, India \\ ${ }^{3} U H S$, Bagalkot, Karnataka, India \\ *Corresponding author
}

\section{Keywords}

Innovations,

Market-Led

extension,

Commodity

interests

\section{Article Info}

Accepted:

22 January 2019

Available Online:

10 February 2019

\section{A B S T R A C T}

India's agricultural extension system is at a pivotal point in its development. During the past 50 years, the Indian extension system has evolved to reflect national priorities. At the outset, extension worked to bring about broad-based rural development. However, the food crises starting in the late 1950s refocused the efforts of extension on food security and increasing food production. The combination of Green Revolution technology in the late 1960s and Training and Visit (T\&V) Extension in the mid-1970s enabled India to achieve food self-sufficiency during the 1980s-1990s. At the same time, malnutrition and poverty continue to be persistent problems for the rural poor. As a result, the Government of India, with the assistance of the World Bank, designed and pilot tested a new extension approach that would decentralize the extension system, refocus it on agricultural diversification, thereby making it more market-oriented. Agricultural sustainability can only be achieved when the ends are the target of the means. This does not include only safe production in terms of consciousness of future generation needs but building up the capacity of the Agricultural system towards increase in productivity cum profit maximization through the new trend of extension services. Under WTO, the globalization/liberalization of market demands farmers at all levels to transform themselves from production and selling in the domestic market to producer cum seller in the wider market scene to realize the optimum returns on their investments. The need for market-led is of necessity by the paradigm shift of present agriculture scenarios which calls for a conversion of the sector into profitoriented business. FAO estimates that 32 per cent of all food produced in the world were lost in 2009 due to lack of post-harvest operation among others. Similarly, 13\% of Gross Domestic Product has reported loss yearly in India due to loss of food grains Existence of many middlemen has also resulted into less return on farmer's investment as well as high cost paid by the consumer. However this loss can be minimized by the Market Led extension approach through adequate supply of information by SWOT analysis of the market, establishing market and agro-processing linkages, direct marketing, and capacity building in terms of improved production and post-harvest operation such as proper handling, grading, standardizing, value addition, packaging as well as storage and transport system. Hence, this paper discusses the innovations, prospects and challenges of the market led extension in view of 21st-century scenario for capacity building of farmers, extension functionaries' stakeholders, and also for policy recommendation towards holistic sustainable agricultural development. 


\section{Introduction}

India's agricultural extension system is the largest in the world. It caters to the technology and information needs of about 100 million farm families. Focus of extension agencies on production technologies yielded very good results and hence India become self reliant in food production. Significantly, the extension system had played its role untiringly in transfer of production technologies from lab to land, besides the agricultural scientists, farmers and marketing network. But the farmers at individual level are not realizing remunerative prices for their produce. Therefore, extension functionaries need to play a major role to build the capacity of the farmers to meet the emerging challenges and make the farmers to realize better prices to their farm produce. But, market-led extension so far is a peripheral issue in the extension scenario. Hence, the extension focus should extend from mere production to market- led extension on endto-end basis.

The Indian farmers have to withstand the possible onslaught of international competitors both in domestic as well as overseas market. The market-led extension would be of an effective instrument to protect the interest of the farming community. The market-led extension will assist the farmers in solving the problems faced in marketing of their produce. The agricultural extension system has so far concentrated their efforts on production technology, whereas the marketled extension will take care of not only the production but also the marketing of their produce. Market-led extension in which agriculture \& economics coupled with extension is the perfect blend for reaching at the door steps of farming community with the help of technology.

A farmer who is a good manager should be able to make as much profit from farming as from any other business. The aim of most of the farmers should be to earn profits. Crops should be grown only to earn profit, not just some profit but as much profit as possible. Farmers need to transform themselves from mere producers-sellers in the domestic market to the producer-cum sellers in the wide market sense to realize the return on their investment, risks and efforts. Market information is an important function ensures the smooth and efficient operation of marketing system. Every one engaged in production and in buying and selling of product is continually in need of market information. Market information is essential to the government for creating policy environment for smooth conduct of business. Market led extension has got the potential to help the farmers and other marketing functionaries in the desired form. Market oriented production and upgrading farmers knowledge about market, market analysis and market intelligence are very essential in the changing context of agricultural scenario. This paper attempts to a peep into the innovations existing in marketing system and strategies for market-led extension for the benefit of farming community.

\section{Innovations in Market Information}

As far as possible, marketing decisions should be based on sound market information. Market news refers to the current information about prices, arrivals and changes in market conditions. This information helps the farmers in taking decisions about when and where to sell his produce. The availability of market news in time and with speed is of the utmost value. Sometimes a person who gets the first market news gains a substantial advantage over his fellow traders who receive in late. Market news quickly become obsolete and requires frequent updating. Reuters Market Light AgTech Pvt. Ltd. and other govt. and 
private organizations provides market information to the farmers through sms. The government also provides day to day information through AGMARKNET Portal and Mobile Apps.

The process of collecting, interpreting, and disseminating information relevant to marketing decisions is known as market intelligence. The role of market intelligence is to reduce the level of risk in decision-making. Through market intelligence the seller finds out what the customer needs and wants. Generation of data on the market intelligence would be a huge task by itself. Departments of market already possess much of the data. Hence, establishment of linkages between agriculture line departments and departments of market strengthens the market-led extension. This includes information relating to such facts as the prices that prevails in the past and market arrival over time. These are essentially a record of what has happened in the past. Market Intelligence is, therefore, of historical in nature. An analysis of past helps us to take decisions about the future. It is an essential function for the formulation of sound prices and trade policy and its successful implementation. The formulation of a sound prices policy requires an analysis of long term trends in the data on prices, arrivals, demand-supply and other information.

\section{Marketing initiatives by commodity interests groups}

It has been realized that the marketing channel for farm products which are highly perishable (fruits, vegetables and flowers) should be as short as possible. Perishable farm produce should move quickly from farmers to consumers. If farmers directly sell their produce to the consumers it will not only save losses but also increase farmers' share in the consumers rupee. Therefore, Commodity
Interests Group (CIG) by the farmers is being encouraged as an alternative channel. Some examples are given below;

\section{Apni Mandi/ Kisan Mandi}

An innovative concept of 'Apni Mandi' has been introduced in some states like Haryana, Punjab and Rajasthan. Apni Mandi is also called 'Kisan Mandi', as it is different from the traditional mandi or market yard, where the produce moves to the buyers through either commission agent or trader. In Apni Mandi, there is a direct contact between the farmer producer and the buyer who is generally the consumer without involvement of middlemen.

The price spread in Apni Mandi is considerable low. These are working satisfactorily in the case of fruits and vegetables. These, Apni Mandis are similar to the Saturday markets of United Kingdom and United States of America.

\section{Hadaspar vegetables market}

Hadaspar vegetable market is a model market for direct marketing of vegetables in Pune city. This sub-market yard is situated nine kms away from Pune city. This belongs to the Pune Municipal Corporation and the fee for using the space in the market is collected by the municipal corporation from the farmers. This is one of the ideal markets in the country for marketing of vegetables. In this market there are no commission agents/middlemen. The market has modern weighing machines for weighing the produce. Buyers purchase vegetables in lots of $100 \mathrm{~kg} /$ of 100 numbers. The purchasers make payment of the value of produce directly to the farmers.

\section{Rythu Bazars}

Rythu bazars have been established in the 
major cities of Andhra Pradesh state with the prime objectives to provide direct link between farmers and consumers in the marketing activity of fruits, vegetables and other essential food items. Both producers and consumers are benefitted from Rythu Bazars as producer's share in consumers rupee is more by 15 to 40 per cent and consumers get fresh vegetables, fruits and food items at 20 to 35 per cent less prices than the prevailing prices in nearby markets. Further, marketing costs are at the minimum level as middlemen are completely eliminated from the marketing activities. The maintenance expenditure of Rythu bazars is being met from financial sources of APMC nearer to the Rythu bazars. Rythu bazars started functioning in AP from January 20, 1999. Presently there are 95 Rythu bazars operating in all the district of the states.

\section{Shetkari Bazars}

Shetkari bazars were established in the state of Maharashtra for the marketing of fruits and vegetables. Shetkari bazar links producers directly to the consumers by eliminating intermediaries and reduces price-spread (marketing margin of intermediaries) and enhances producer's share in consumers' rupee. Thus, these markets increase the farm income, well being of the farmers and bring stability in prices of horticultural and plantation crops.

\section{Krishak Bazars}

On the lines of Rythu Bazars in Andhra Pradesh and Uzhavar Sandies in Tamil Nadu, Govt. of Odisha has taken a programme of establishing Krushak Bazars in the states of Odisha in the year 2000-01 with the purpose to empower farmer-producer and to ensure products at affordable prices to the consumers. The government provides following incentives for opening of the Krushak bazars in the states:
Provides 1 to 2 acres of land at suitable place, free of cost for establishing the bazar.

A cluster/group of villages within the proximity of market area and farmers growing vegetables are identified having the surplus produce for sale.

The identified farmers are allowed to use marketing facilities so that there is no interventions of middlemen and farmers get better price for their produce.

\section{Mother dairy Booths}

Mother Dairy basically handling milk in Delhi, was asked to try its hand in retail vegetable marketing by direct purchasing vegetables from the farmers, moving them in specially build vehicles, storing them in air conditioned godowns and distribute them to the consumers through its retail outlets in 1989 after the notorious onion and potato price crisis.

Mother dairy management has opened retail outlets in almost all important colonies of Delhi for providing vegetables to the consumers at reasonable prices.

\section{Marketing initiatives by farmers cooperatives}

An innovative institutional mechanism and marketing initiatives by farmers' cooperatives in Maharashtra like Mahagrapes, Mahabanana, Mahaanar, Mahaorange, Mahamango are engaged in cultivation, processing and marketing of their produce. The commodity wise (grapes, banana, mango, pomegranate and orange) successful growers cooperative societies are engaged in cultivation and selling of their produce in the domestic as well as international market. The main objective of these farmers cooperatives to focus on marketing, boost the export, enhance the profit of the growers and update 
the farmers on latest technology in farming.

\section{National Agriculture Market (NAM)}

National Agriculture Market (NAM) is a panIndia electronic trading portal, which networks the existing APMC mandis to create a unified national market for agricultural commodities. The NAM portal provides a single window service for all APMC related information and services. This includes commodity arrivals $\&$ prices, buy $\&$ sell trade offers, provision to respond to trade offers, among other services. While material flow (agriculture produce) continues to happen through mandis, an online market reduces transaction costs and information asymmetry. In order to facilitate both-unification of market and online trading, it is necessary for the states to undertake reforms prior to seeking assistance under the scheme in respect of (i) a single license to be valid across the State, (ii) single point levy of market fee and (iii) provision for electronic auction as a mode for price discovery. NAM is being deployed in selected 585 regulated wholesale markets in States/UTs desirous of joining the e-platform. Small Farmers' Agribusiness Consortium (SFAC) is operating the NAM as the implementing agency with technical support from the Strategic Partner (SP). To facilitate assaying of commodities for trading on NAM, common tradable parameters have been developed for 90 commodities. A total of 585 Mandis across 16 States and two UTs are live on e-NAM as on 31.01.2019.

\section{Contract farming}

Contract farming is a forward agreement between farmers and wholesalers/retailers for the production and supply of agricultural commodities and the agreement is generally made at predetermined prices. Through the agreement, the buyers can also provide technical and production support to the grower. The farmers, through the agreement, commit themselves to produce a specific commodity at the buyer-desire quality. Since the Government is a major stakeholder in the contract farming (since most of the produce today is procured by the Government, it is equivalent to farmers producing only for the Government, a variation of contract farming), it is essential to reduce the load on the central and State level procurement system. Contract farming also paves way for private investment which has the potential to boost the entire sector. Contract farming also brings about a market focus in terms of the selection of crops so that farmers could grow that crop and benefit from it immensely.

Farmers get a stable, consistent income through contract farming and this act as an incentive for the farmer to produce quality produce and also add value to it (like removing the husk and selling only the pulse inside). Contract farming also generates employment in the sense that for landless agricultural farmers, contract farming might prove to be a source of sustenance. Contract farming also promotes rural self-reliance by utilizing the local resources to meet the challenges. To protect farmers from price risks and provide incentives to buyers to procure produce directly from farmers, the agriculture ministry has drafted a model contract farming act (The Indian Contract (Amendment) Bill, 2017), which has been tabled in the Parliament recently for amendment. The draft copy of the 'Model Contract Farming Act 2018' is on the Ministry's (http://www.agricoop.nic.in) for public consultation.

\section{Retail marketing}

Retailing, one of the largest sectors in the global economy, is going through a transition 
phase not only in India but the world over. Retailing can be defined as the buying and selling of goods and services. It can also be defined as the timely delivery of goods and services demanded by the customers at prices that are competitive and affordable. Retailing involves a direct interface with the customer and the coordination of business activities from end to end -right from the concept or design stage of a product or offering, to its delivery and post delivery service to the customer. The industry has contributed to the economic growth of many countries and is undoubtedly one of the fastest changing and dynamic industries in the world today.

Retail operations enable a store to function smoothly without any hindrances. The significant types of retail operations consist of: department store, specialty store, discount/mass merchandisers, warehouse/wholesale clubs and faculty outlet. Retail management system targets small and midsize retailer seeking to automate their stores. For a long time, the corner grocery store was the only choice available to the customer, especially in the urban areas. This is slowly giving way to international formats of retailing. The traditional food and grocery segment has been the emergence of supermarkets/grocery chains (Food World, Nilgiris, Apna Bazar), convenience stores (Convenio, HJP Supermarket) and fast food chains.

\section{The strategies for market-led extension}

In the changing context of agricultural scenario, extension professional has to play a crucial role for dissemination of most recent market information to the farming community and enabling farmers to get optimum returns out of the enterprise. Market-led extension has got the potential to help the farmers and other marketing functionaries in the desired form. We have to identify the market demands in terms of produce for the present and the future. Preparation of a strategic plan in market-led extension at district, block, and village level will have to be one of the important functions of state machinery of agricultural extension. A multidisciplinary team of experts drawn from local Agricultural University, KVK, NGOs, State Agricultural departments, input agency will have to be involved in preparation of the strategic plan. Some of the suggestions are given below;

SWOT analysis of the market: Strengths (demand, high marketability, good price etc.), Weaknesses (the reverse of the above), Opportunities (export to other places, appropriate time of selling etc.) and Threats (imports and perishability of the products etc.) need to be analyzed about the markets. Accordingly, the farmers need to be made aware of this analysis for planning production and marketing.

Organization of Farmers' Interest Groups (FIGs) on commodity basis and building their capabilities with regard to management of their farm enterprise.

Supporting and enhancing the capacities of locally established groups under various schemes /programmers like watershed committees, users groups, SHGs, water users' associations, thrift and credit groups. These groups need to be educated on the importance, utility and benefit of self-help action.

Enhancing the interactive and communication skills of the farmers to exchange their views with customers and other market forces (middlemen) for getting feedback and gain the bargaining during direct marketing ex. Rythu Bazars, Agri-mandi and Uzhavar Sandies etc.

Establishing marketing and agro-processing linkages between farmers' groups, markets and private processors.

Advice on product planning: selection of 
crops to be grown and varieties suiting the land holding and marketability of produce will be the starting point of agri-enterprise. Extension system plays an important role in providing information in this regard.

Educating the farming community: to treat agriculture as an entrepreneurial activity and accordingly plan various phases of crop production and marketing.

Direct marketing: farmers need to be informed about the benefits of direct marketing. In some of the states, Rytu Bazars in AP, Apni Mandis in Punjab and Haryan and Uzhavar Sandies in Tamil Nadu have shown success.

Capacity building of FIGs in terms of improved production, post harvest operations, storage and transport and marketing.

Acquiring complete market intelligence regularly on various aspects of markets

Regular usage of internet facility through computers to get updated on market intelligence.

Publication of agricultural market information in news papers, radio and television besides internet.

Organization of study tours of the successful farmers/ FIGs for various operations with similar socio-economic and farming systems as the farmers learn more from each other.

Production of video films of success stories of commodity specific farmers, regular updating of market intelligence.

Production technologies like improved varieties, organic farming, usage of biofertilizers and bio-pesticides, IPM, INM, and right methods of harvesting etc.
Post-harvest management like processing, grading, standardization of produce, value addition, packaging, storage, certification, etc. with reference to food grains, fruits and vegetables, eggs, poultry, fish, etc.

The strategy for market-led agricultural extension in India has to include establishment of Agribusiness Cooperative Centers at every village or for a group of villages, which may be maintained by trained village leader (volunteers). These Agribusiness centers will have to provide information on market intelligence, production technology and will also supply inputs including marketing and value addition to the produce.

Need for contract farming: Since the Government is a major stakeholder in the contract farming, it is essential to reduce the load on the central and state level procurement system and for high returns to the farming community.

The existing supply input management is mainly based upon on individual efforts. Reengineering the supply chain through collaborative efforts through agribusiness cooperatives at village, district and state level or self-help groups or farmers organization etc., is essential for promotion of agribusiness.

Farmers also need special training on specific standards for export (Euro-gap, codex standards etc.). Further, arrangements have to be made for public-private partnership for input supply, sales of produce, export etc.

\section{Epilogue}

In order to achieve the increased competitiveness of Indian agriculture there is a need for innovations in market-led extension. The strategy for market-led 
agricultural extension in India has to include establishment of Agribusiness Cooperative Centers at every village or for a group of villages, which may be maintained by trained village leader (volunteers). These Agribusiness centers will have to provide information on market intelligence, production technology and will also supply inputs including marketing and value addition to the producers. Paradigm shift focus from 'supply driven' to 'demand driven' and produce according to the market needs and farmers have to earn high returns. Market-led extension establishes its position by helping the farmers realize high returns for the produce, minimize the production costs, and improve the product value and marketability. We have to identify the market demands in terms of produce for the present and the future.

\section{References}

Advances in Agricultural Extension (RAE002). Market Led Extension. School of Agriculture, Indira Gandhi National Open University, New Delhi.

Food and Agricultural Organization: www.fao.org

http://mospi.gov.in/nss_press_note

Market-Led Extension (2008). Post Graduate Diploma in Agricultural Extension Management (PGDAEM) published by National Institute of Agricultural Extension Management (MANAGE), Rajendranagar, Hyderabad - 500 030, Andhra Pradesh, India.

Policy Framework for Agricultural Extension, Extension Division, Dept. of Agriculture \& Cooperation, Ministry of Agriculture, Government of India, 2001.

\section{How to cite this article:}

Krishna, D.K., N.V. Kumbhare, Itigi Prabhakar, B.S. Swetha and Ashoka, N. 2019. Innovations in Market-Led Extension. Int.J.Curr.Microbiol.App.Sci. 8(02): 3256-3263.

doi: https://doi.org/10.20546/ijcmas.2019.802.380 